\title{
Evidence of the Interaction Between Crop Species and Organic Amendments: Modelling of the Differential Grain Yield Response of Wheat, Soybean, and Canola to Organic Amendments
}

\author{
Roger Nkoa ${ }^{1}$, Boris Ondoua ${ }^{2}$, Paul Voroney ${ }^{1} \&$ James Tambong ${ }^{3}$ \\ ${ }^{1}$ University of Guelph, Ontario Agricultural College, School of Environmental Sciences, 50 Stone Road East. \\ Guelph, Ontario, N1G 2W1, Canada \\ ${ }^{2}$ Lambton College, London Road, Sarnia, N7S 4X7, Canada \\ ${ }^{3}$ Agriculture and Agri-Food Canada, 960 Carling Avenue, Ottawa, Ontario, Canada. K1A 0C6, Canada \\ Correspondence: Roger Nkoa, School of Environmental Sciences, 50 Stone Road East. Guelph, Ontario, N1G \\ 2W1, Canada. Tel: 1-519-824-4120 ext. 52645. E-mail: rnkoa@uoguelph.ca
}

Received: July 17, 2014 Accepted: September 17, 2014 Online Published: September 23, 2014

doi:10.5539/sar.v3n4p33 URL: http://dx.doi.org/10.5539/sar.v3n4p33

\begin{abstract}
Knowledge on the interaction between plants and organic amendments is critical for the basic understanding of agroecosystems sustainability. Organic amendments are of great interest in agriculture by virtue of their ability to restore lost soil organic carbon in eroded or conventionally cultivated soils. The major objective of this study was to demonstrate and model the differential response of crop species to organic amendments. Despite the potential of such an interaction to improve crop production, it has never been formally demonstrated in a planned experiment. A two-year greenhouse experiment set as $3 \times 3 \times 5$ factorial in a strip-split plot design was conducted. The effects of crop species, type of organic amendment, and application rates on grain yield of soybean, canola, and wheat were evaluated. To account for the asymmetry of the concave responses of soybean, mathematical transcendental models were fitted, for the first time, to yield data. The interaction between crop species and amended soils was highly significant. Soybean displayed concave transcendental yield responses whereas canola and wheat exhibited negative exponential responses, irrespective of the type of amendment. Turkey compost outperformed turkey litter and beef manure by $30 \%$ and $52 \%$, respectively, with respect to soybean production; whereas turkey litter outperformed turkey compost and beef manure by $144 \%$ and $264 \%$, respectively, with respect to canola and wheat production. It is concluded that in greenhouse settings and perhaps field conditions, growth and development of crop species can be enhanced by matching the specific characteristics of organic amendments to the specific nutrients demand of crop species.
\end{abstract}

Keywords: canola, compost, grain yield, manure, organic amendment, organic agriculture, soybean, wheat

\section{Introduction}

The United Nations estimates that the world population will reach 9.4 billion by 2050 and 10 billion by 2100 (Cohen, 2003). This explosive population growth rate is unmatched by the growth rate of world food production, which has raised concerns about world food security. To meet the challenges of food security, various agricultural strategies have been proposed: intensification of agriculture (more lands, fertilizers, pesticides, and water), use of new technologies (equipment, precision-farming), and the creation of genetically modified organisms. Unfortunately these strategies, with the exception of precision farming, have been linked to a heavy environmental cost: eutrophication and contamination of ground and surface waters, land degradation and desertification, loss of soil organic carbon, climate change, etc. (Lal, 2009). Farming systems such as organic agriculture and sustainable conventional practices that make use of agroecological principles have been proposed as ecosystem approaches to address these environmental issues. In fact, opportunities to increase yields while improving soil health and quality already exist. One such opportunity is precision nutrient management, or the agronomic exploitation of the interaction between crop and the environment (genotype $\mathrm{x}$ environment).

Genotype $\mathrm{x}$ environment interaction is the differential response of genotypes across different environments. The phenomenon has been exploited for decades by plant breeders in determining the adaptation and stability of new genotypes (Berger et al., 2002; Beyene et al., 2011). It is widely accepted that yield stability across regions and 
high productivity are the most desirable attributes of crop varieties (Thanki et al., 2010; Nizam et al., 2011). Thus, cultivars that display high average yields across multiple locations are preferred over those that display the highest potential yield at specific locations. The approach is strategically and commercially sound, as it is more convenient and profitable for seed producers to market their products to larger markets (regional) than to individual local ones. In the field of farming systems, specifically in the area of plant nutrition and soil fertility, crop species may interact with amended soil media (environment), and respond differently depending upon the type of organic amendment (manures, composts) they are fertilized with. In this case, yields could be increased at the regional scale through a reverse approach to that used by crop breeders and which would consist in selecting, on a per farm basis, the best combinations crop species/amendment type without additional or excessive nutrient inputs. There has been little research devoted to the application of the genotype $\mathrm{x}$ environment concept to farming or cropping systems. Thus, very few studies, if any, have reported the interaction between crop species and organic amendments. Research studies on woody horticultural crops have hinted at the existence of interactions between shrub species and compost type (Gonzalez \& Cooperband, 2002; Maynard, 1998). However, none of these studies involved experiments formally designed to capture and measure the interaction between the woody species and the type of compost. The interaction between lettuce (Lactuca sativa L.), radish (Raphanus sativus L.) and soil type has been highlighted with respect to the uptake of radioactive isotopes ${ }^{137} \mathrm{Cs}$ and ${ }^{90} \mathrm{Sr}$ in soil affected by the Chernobyl nuclear accident (Melnitchouck \& Hodson, 2004). Recently, it was shown that the effects of organic fertilizers were genotype-dependent (Lazcano et al., 2011). However, the rabbit manure and vermicompost evaluated in this study made up only $25 \%$ of each integrated fertilization treatment; the remainder portions $(75 \%)$ were inorganic fertilizers.

Organic amendments (composts, manures, green manures) can be viewed as complex nutrient substrates characterized by differing physical, chemical, and biological properties. The nutrient composition of fresh or composted manures depends upon factors such as the type of livestock, feed rations and additives, the type of bedding, and the method of manure handling and storage. Specifically, manure is a useful organic fertilizer that can supply inexpensive nutrients for crop production (Lafleur et al., 2012), and an effective organic amendment that can improve soil physical and chemical properties (Larney et al., 2000). Thus, a wealth of studies have demonstrated that composts and manures reduce soil bulk density while increasing porosity and hydraulic conductivity (Gonzalez \& Cooperband, 2002; Wong et al., 1999); improve total soil carbon and tilth (Raviv, 2005); increase the availability of macro- and microelements (Qian et al., 2003); improve crop yield (Mooleki et al., 2004). Despite the aforementioned benefits, agriculturalists and farmers face challenges when using animal manures and composts. These challenges include: low nutrient content per unit weight, variability and availability of nutrient content, a balance of available nutrients that often does not meet the relative nutrient requirements of the specific crop (Shoenau \& Davis, 2006). In conventional agricultural systems, the issues of nutrient amount and balance can be resolved quite effectively through the application of supplemental inorganic fertilizers following soil, plant, and manure/compost tests. In organic farming systems, manufactured inorganic fertilizers are prohibited which makes the issue harder to resolve. One possible solution would be to match manures or composts to specific crop species' requirements.

The variability of nutrient contents and balance among manure and compost sources on the one hand, and among crop species with respect to their specific and respective nutrient requirements on the other hand, raises the likelihood of interactions between animal manures/composts and crop species. In other words, it raises the possibility of differential responses of crop species to differing organic amendment sources. The phenomenon of the interaction crop species $x$ organic amendment has not yet been fully investigated in greenhouse and field crops production despite the large body of literature on the effects of manures and composts on various field crops. Much remains unknown about matching the type of organic amendment to specific crop species requirements. Identification of optimal matches would significantly contribute to the improvement of the productivity of agricultural systems that rely on organic amendments without increasing the environmental cost of production. Two approaches have been used in studies that have compared different types of organic amendments: the holistic and the elemental. For the elemental approach, a given element or nutrient is selected to standardize the different types of manure (e.g. Zaller \& Köpke, 2004). Here, treatment rates are increments of a given amount of the selected element or nutrient. That is, one element is the independent variable to which the whole manure effect is attributed to. Major setbacks of this approach are: i) interpretations of the results may be inaccurate and misleading as any selected element covaries with other essential elements; ii) different type of responses to a given organic amendment may be recorded depending upon the type of element selected, due to the fact that each essential element has its own uptake and assimilation mechanism (Nkoa et al., 2003; Marschner, 2012). For the holistic approach, manure treatments are standardized on the basis of the dry weight or volume of "whole manures" (e.g. Saviozzi et al., 1999; Hati et al., 2006; Rotz et al., 2011). It is the most 
commonly used method in the literature, and the one we have used in this study.

The objectives of this study were: i) to demonstrate and formally quantify the interactions between three types of organic amendments (turkey compost, turkey litter, and beef manure) and three field crop species (soybean, canola, and wheat) under greenhouse settings; and ii) to model and characterize the yield responses of these three crops species to the three organic amendments. We have hypothesized that the effect of turkey compost, turkey litter, and beef manure on the grain yields of soybean, canola, and wheat would vary among these crop species, and as a result, the responses of the crops would differ in nature and magnitude depending upon the type of organic amendment used.

\section{Materials and Methods}

\subsection{Plant and Experiment Management}

Four seedlings of a soybean hybrid (Glycine max L. cv. Pioneer 93M62), Canola (Brassica napus L. cv. Pioneer 46H75), and a wheat hybrid (Triticum aestivum) were transplanted into 5-L plastic pots filled with amended soil, in a ventilated greenhouse on 2 January 2011 and the procedure was repeated the following year, on 5 May 2012. Soybean and canola plants were subsequently thinned to 1 plant/pot, and wheat plants were thinned to 2 plants/pot. Teeswater silt loam (Grey-brown Luvisol) was collected (0 to 40-cm depth) from a certified organic farm in Riverstown, Ontario (Table 1) and passed through a 10-mesh screen before potting. For each plastic pot, $5 \mathrm{~kg}$ (dry weight) of soil was thoroughly mixed with $60,120,180$, and $240 \mathrm{~g}$ (dry weight) of either fresh turkey broiler compost, turkey broiler litter or beef manure, giving rise to the following percent rates: 1.2, 2.4, 3.6, and 4.8 , respectively. Pots were topped with $1 \mathrm{~cm}$ layer of washed sand to control for fungus gnats and shoreflies. Manures and compost were obtained from certified organic farms in the Wellington County, Ontario. Soil, manure, and compost samples were sent to a commercial laboratory (SGS-AgriFood Laboratories) where their chemical and physical properties were determined. (Table 1).

Table 1. Chemical and physical properties (dry weight basis) of the organic farm's soil, turkey compost, turkey broiler litter, and beef manure used in the study

\begin{tabular}{lllll}
\hline Properties & Organic farm's Soil & Turkey compost & Turkey litter & Beef manure \\
\hline Ammonium-N (ppm) & 2.4 & $2998.14 \mathrm{ppm}$ & $13085.54 \mathrm{ppm}$ & 1351.60 \\
Nitrate-N (ppm) & 21.4 & - & - & \\
Phosphorus (ppm) & $15($ Bray) & 12700 & 8900 & 1200 \\
Calcium (ppm) & 1996 & 30700 & 12100 & 6000 \\
Potassium (ppm) & 81 & 12100 & 10500 & 5600 \\
Magnesium (ppm) & 412 & 6100 & 3600 & 2000 \\
Zinc (ppm) & 0.8 & 347.03 & 340.85 & 21.25 \\
Manganese (ppm) & 12.6 & 418.63 & 308.47 & 22.24 \\
Copper (ppm) & 0.3 & 102.99 & 45.18 & 5.01 \\
Iron (ppm) & 24.3 & 1896.22 & 381.59 & 508.62 \\
Boron (ppm) & 0.35 & 21.17 & 8.03 & 7.33 \\
Organic Carbon & - & $10.54 \%$ & $14.43 \%$ & $7.60 \%$ \\
Carbon/Nitrogen ratio & - & 10.14 & 7.25 & 17.25 \\
pH & 7.1 & - & - & - \\
Organic matter (\%) & $3.3 \%$ & - & - & - \\
CEC (MEQ/100g) & 14.8 & - & - & - \\
Base saturation (\%) & $1.4(\mathrm{~K}) ; 23.3(\mathrm{Mg}) ;$ & - & - & - \\
& $67.3(\mathrm{Ca}) ; 8.1(\mathrm{H})$ & & & - \\
Sand; silt; clay (\%) & $30 ; 57 ; 13$ & - & $36.84 \%$ & $20.69 \%$ \\
Dry matter & - & $45.52 \%$ & 5.38 & 1.37 \\
EC (mmhos/cm) & - & 5.82 & 1.99 & 0.44 \\
Nitrogen (\%) & - & 1.04 & & \\
& & & &
\end{tabular}


The experimental design was a $3 \times 3 \times 5$ factorial in a strip-split plot design with three replications. Crop species (soybean, canola, wheat), type of organic amendment (beef manure, turkey litter, turkey compost), and the rate of organic amendment $(0 \%, 1.2 \%, 2.4 \%, 3.6 \%$,and $4.8 \%$, dry weights) were the vertical, horizontal, and sub-plot factors, respectively. Each experimental unit was made up of three plastic pots. The plastic pots were laid in staggered rows to minimize the effects of intraspecific light competition resulting from differing growth rates among treatments. Natural lighting in the glasshouse was supplemented by high-pressure sodium lamps (HPS, P.L 780/N 400, P. L. Lighting Systems, ON, Canada) that provided a photosynthetic photon flux density of 300 $\mu \mathrm{mol} \mathrm{m} \mathrm{s}^{-1}$ at pot level. Plants were maintained on a $16-\mathrm{h}$ light $/ 8$-h dark cycle for the first 60 days after transplanting, and then on a 14-h light/10-h dark cycle to trigger the flowering process of soybean. Night and day temperatures were set at $18{ }^{\circ} \mathrm{C}$ and $22{ }^{\circ} \mathrm{C}$, respectively. All plants were watered daily to field capacity of the amended soil. Each plastic pot was trickle-irrigated at increasing rates: $10 \mathrm{ml} \mathrm{day}^{-1}$ (weeks 1-2); $50 \mathrm{ml} \mathrm{day}^{-1}$ (week 3); $100 \mathrm{ml} \mathrm{day}{ }^{-1}$ (weeks 4-5); $150 \mathrm{ml} \mathrm{day}{ }^{-1}$ (weeks 5-6, soybean and wheat); $200 \mathrm{ml} \mathrm{day}^{-1}$ (week 5-6, canola); $200 \mathrm{ml} \mathrm{day}^{-1}$ (weeks 7-8, soybean and wheat); $300 \mathrm{ml}$ day $^{-1}$ (weeks 7-8, canola); $300 \mathrm{ml} \mathrm{day}^{-1}$ (weeks 9-12, soybean and wheat); $400 \mathrm{ml} \mathrm{day}^{-1}$ (weeks 9-12, canola.). Three biological control systems were used to control the populations of thrips, aphids, and two-spotted spider mites on soybean and canola plants: Swirskii-System (Amblyseius swirskii, Biobest ${ }^{\circledR}$ ); Koppert Biological System (Aphidoletes aphidimyza); Aphidius-Mix-System (Aphidius colemani; Aphidius ervi, Biobest ${ }^{\circledR}$ ). One to three grams of each system were sprayed over plants both at transplanting and whenever insect infestation appeared on plant leaves or on the yellow sticky traps. To get a better insight on the effect of the three organic amendments on the growth rates of soybean and canola plants without destroying the sampled plants, their height (instead of dry biomass) were measured every other week until the first inflorescence appeared on a canola plant. Height was measured from the junction of the stem and the soil to the last appeared leaf of soybean and canola plants. The variable height was not measured on wheat plants due to tillering and lodging.

\subsection{Statistical Analysis and Response Modelling}

To formally demonstrate the interaction between crop species and organic amendments, and the differential response of the model crops to the organic amendments used in this experiment, two type of statistical analysis were used: an analysis of variance and regression analysis. The analysis of variances of grain yields was pooled over years and performed for the $3 \times 3 \times 5$ factorial in a strip-split plot design with three replications. All statistical computations were done using the Statistical Analysis System (SAS Institute Inc., 1996). Responses of soybean, canola and wheat, when grown on soils amended with turkey compost, turkey litter and beef manure at increasing rates, were fitted to mathematical functions. To account for the asymmetric concave responses of soybean, transcendental models (non-algebraic) were fitted to yield data. The soybean yield response $f_{l}$ was expressed as follows:

$$
f_{l}(x)=b_{0} x e_{1}^{-b}+b_{2}
$$

Where: $x$ is the organic amendment rate expressed as the proportion of soil in the pot (dry weight basis); $b_{2}$ is a constant representing the $y$-intercept; and $b_{0}$ and $b_{1}$ are two constants.

Yield responses $\left(f_{2}\right)$ of canola and wheat were fitted to negative exponential models expressed as follows:

$$
f_{2}(x)=b_{o}\left(1-e^{-\left(b x+b_{2}\right.}\right)
$$

Where: $x$ is the organic amendment rate; and $b_{0}, b_{1}$, and $b_{2}$ are constants.

Nonlinear regression analyses were carried out using the NLIN procedure and the Gauss-Newton iterative method (SAS Institute Inc., 1996).

\section{Results}

\subsection{Effects of Turkey Compost, Turkey Litter, and Beef Manure on the Growth Rate of Soybean and Canola}

Growth rate, or elongation rate, was estimated as the average daily height increment of individual soybean or canola plants at a given growth stage. Generally, the rates of height increase were slow the first 28 days, and then dramatically picked up irrespective of the crop species or the rate of amendment (Figure 1 soybean/canola-abcd). However, unlike the case of canola, the respective effects of turkey compost, turkey litter, and beef manure on soybean height differed in magnitude 14 days after transplanting. Regardless of the rate of amendment, turkey compost had the highest growth rates relative to turkey litter and beef manure. Whereas in canola, growth rates induced by turkey compost, turkey litter, and beef manure were generally similar irrespective of the rate of amendment, with the exception of turkey litter which displayed a slower rate at $4.8 \%$ and 42 days after transplanting (Figure 1 canola-d). In general, higher amendment rates at 42 days after seeding resulted in the decrease in the elongation rates of both soybean and canola plants. For examples, the growth rate of soybean 
plants decreased dramatically, at 42 days after seeding, with increased levels in the soil of: i) turkey compost: 24 ; $20 ; 19$; and $15 \mathrm{~mm} /$ day at $1.2 ; 2.4 ; 3.6$; and $4.8 \%$ amendment rates, respectively; ii) turkey litter $14 ; 10 ; 4 ;$ and 0 $\mathrm{mm}$ /day at $1.2 ; 2.4 ; 3.6$; and $4.8 \%$ amendment rates, respectively); and iii) beef manure $11 ; 13 ; 11 ; 11 \mathrm{~mm} /$ day at $1.2 ; 2.4 ; 3.6$; and $4.8 \%$ amendment rates, respectively (Figure 1 soybean-abcd). With respect to canola, the effect of increased levels of organic amendments in the soil had a lesser impact on plant elongation rate: i) turkey compost: $10 ; 10 ; 10 \mathrm{~mm} /$ day at $1.2 ; 2.4 ; 3.6$; and $4.8 \%$ amendment rates, respectively; ii) turkey litter: $11 ; 10 ; 8$; $6 \mathrm{~mm} /$ day at $1.2 ; 2.4 ; 3.6$; and $4.8 \%$ amendment rates, respectively; and iii) beef manure: $10 ; 10 ; 11 ; 11 \mathrm{~mm} /$ day at $1.2 ; 2.4 ; 3.6$; and $4.8 \%$ amendment rates, respectively (Figure 1 canola-abcd).

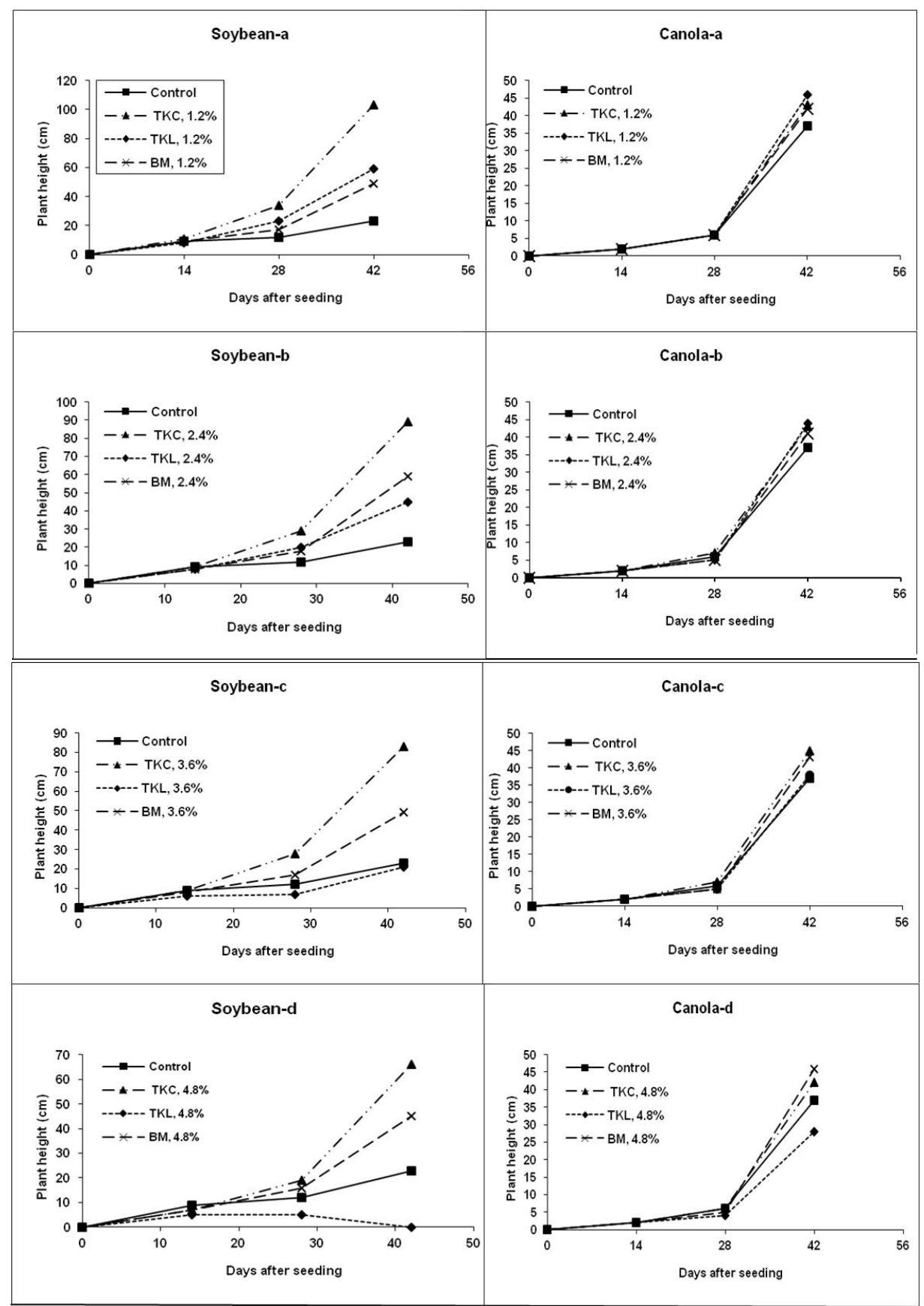

Figure 1. Soybean/canola-abcd

Time-course of the height of soybean and canola plants during the first 42 days after seeding when grown in soils amended with turkey compost, turkey litter, and beef manure at the rate (organic amendment/soil dry weight) of $1.2 \%$ (a), $2.4 \%$ (b), $3.6 \%$ (c), and $4.8 \%$ (d). 


\subsection{Interactions Between Crop Species and Organic Amendments}

Differences between crop species were highly significant, and so were the main effects of organic amendment and organic amendment application rate (Table 2). The three two-factor interactions, crop species $\times$ organic amendment, crop species $\times$ organic amendment application rate, and organic amendment $x$ organic amendment application rate, were highly significant. These results indicate that: i) the effects of both type and rate of organic amendment varied among the crop species tested (soybean, canola, and wheat); ii) the effects of organic amendment rates varied among the type of organic amendment. Similarly, the three-factor interaction, crop species $\times$ organic amendment $\times$ organic amendment/soil ratio, was highly significant, indicating that the grain yield responses of soybean, canola and wheat varied depending upon the type and the rate of the organic amendment applied (Table 2). When the observed grain yields of soybean, canola and wheat were fitted to transcendental and negative exponential functions, eight of the nine estimated regression equations were significant $(p<0.05)$ (Table 3). The pattern of soybean response to turkey compost, turkey litter, and beef manure was different than those of canola and wheat.

\subsection{Grain Yield Response of Soybean to Turkey Compost, Turkey Litter, and Beef Manure}

Grain yield responses of soybean to increasing rates of turkey compost, turkey litter, and beef manure were characterized by a linear and fast response section at lower rates, followed by a slower, concave section around the maximum rate (slower rate of increase and decrease), and then a linear decrease at higher rates (Figure 2). The resulting graph opens downward and is asymmetric, making the observed data unfit for quadratic or cubic functions. The transcendental regression equations (Equation 1) for grain yield of soybean grown on soil amended with turkey compost and beef manure were significant at $1 \%$ and $3 \%$, respectively (Table 3 ), indicating that grain yield responses of soybean to turkey compost and beef manure amendments can be adequately described by the transcendental mathematical function. The computed $\mathrm{R}^{2}$ values were 0.99 for both regressions indicating that $99 \%$ of the total variations in the mean yields of soybean grown on soil amended with turkey compost and beef manure were explained by the estimated transcendental regression equations estimated. The transcendental regression of the yield of soybean grown on soil amended with turkey litter displayed a lower $\mathrm{R}^{2}$ (0.89). This can be explained by the fact that the transcendental equation $\mathrm{b}_{0} x \mathrm{e}^{-\mathrm{b}}{ }_{1}^{x}+\mathrm{b}_{2}=0$ cannot be solved for $x$. Thus, when the $4.8 \%$ rate was left out of the regression analysis, the transcendental equation became significant at $1 \%$ level with a $\mathrm{R}^{2}=0.99$. This issue would be nonexistent in field experiments where a high rate such $4.8 \%$ would be impractical. Consequently, it would be unlikely to have a grain yield equal to zero under farm conditions. The predicted maximum rates of turkey compost, turkey litter and beef manure were $1.8 \%, 1.1 \%$, and $2.6 \%$, respectively, which corresponded to maximum grain yields of $32 \pm 2.0 ; 25 \pm 2.0$; and $19 \pm 4.0 \mathrm{~g} / \mathrm{plant}$, respectively.

Table 2. Analysis of variance of grain yields of three crop species (soybean, canola and wheat) tested on three organic amendments (turkey compost; turkey litter; beef manure) at five organic amendment/soil ratios $(0 ; 1.2$; $2.3 ; 3.6 ; 4.8 \%$ ) in a strip-split-plot design with three replications

\begin{tabular}{lrrc}
\hline Source of variation & DF & Sum of squares & Pr $>$ F \\
\hline Replication & 2 & 26.96 & \\
Crop species (A) & 2 & 2193.59 & 0.0005 \\
Error (a) & 4 & 49.48 & \\
Organic amendment (B) & 2 & 322.12 & 0.0001 \\
Error (b) & 4 & 2.84 & \\
$\mathrm{~A} \times \mathrm{B}$ & 4 & 1973.83 & 0.0001 \\
Error (c) & 8 & 13.87 & \\
Organic amendment/Soil ratio (C) & 4 & 1879.67 & 0.0001 \\
$\mathrm{~A} \times \mathrm{C}$ & 8 & 1095.90 & 0.0001 \\
$\mathrm{~B} \times \mathrm{C}$ & 8 & 199.78 & 0.0001 \\
$\mathrm{~A} \times \mathrm{B} \times \mathrm{C}$ & 16 & 1125.80 & 0.0001 \\
Error (d) & 72 & 248.31 & \\
Total & 134 & & \\
\hline
\end{tabular}




\subsection{Grain Yield Response of Canola and Wheat to Turkey Compost, Turkey Litter, and Beef Manure}

In contrast to soybean, grain yield responses of canola and wheat to increasing rates of turkey compost, turkey litter, and beef manure did not exhibit maximal yields or toxicity effects within the range of organic amendment rates tested (Figure 3 and Figure 4). In all cases, the pattern of grain yield response over organic amendment rates was initially fast at lower rates, followed by a slower yield increase for each unit of amendment added. The negative-exponential regression equations of canola and wheat grown on soil amended with turkey compost, turkey litter, and beef manure were both highly significant $(p<0.001)$ (Table 3$)$. This indicates that the grain yield responses of canola and wheat to turkey compost, turkey litter and beef manure amendments can be adequately described by the negative exponential function (Equation 2). The computed $\mathrm{R}^{2}$ values were 0.99 for all of the regressions indicating that $99 \%$ of the total variations in the mean yields of canola and wheat (grown on soil amended with turkey compost, turkey litter and beef manure) were explained by the negative-exponential-regression equations estimated. The estimated maximum grain yields of canola when grown on soil amended with turkey compost, turkey litter, and beef manure were $8 \pm 0.8,20 \pm 1.0$, and $5 \pm 0.5$ $\mathrm{g} /$ plant, respectively. For wheat, these maxima were $10 \pm 0.2,14 \pm 2.9$, and $9 \pm 0.8 \mathrm{~g} / \mathrm{plant}$, respectively.

\section{Discussion}

Plant growth is the result of rapid cell mitosis at meristems, and as new cells differentiate, they provide new plant tissues. This growth is dependent upon environmental and soil factors such as light, temperature, soil moisture and mineral contents. Plant growth rate, expressed as internode elongation per unit of time, is not necessarily correlated to plant grain yield, however, they can altogether shed light on the various impacts that growth media can have on the development of plants. Thus, for this study, the type of organic amendment had an impact on both internode elongation and grain yield of individual soybean plants; whereas for canola, the type of organic amendment did not affect the elongation rate of individual plants, bud did significantly impact the grain yields of plants (Figure 1 soybean/canola-abcd; Figure 2).

Table 3. Nonlinear regression analysis between grain yields of soybean, canola, wheat and organic amendment/soil ratios

\begin{tabular}{llcrc}
\hline Regression & Source & $\begin{array}{l}\text { Degree } \\
\text { freedom }\end{array}$ & $\begin{array}{c}\text { of } \\
\text { Squares }\end{array}$ & of $>\mathrm{F}$ \\
\hline Soybean on turkey & Model: $\mathrm{Y}=37.5 x \mathrm{e}^{-0.55 x}+6.5$ & 2 & 390.8 & 0.0027 \\
compost & Error & 2 & 1.06 & \\
Soybean on turkey & Model: $\mathrm{Y}=59.1 x \mathrm{e}^{-0.95 x}+1.9$ & 2 & 334.3 & 0.1108 \\
litter & Error & 2 & 41.6 & \\
Soybean on beef & Model: $\mathrm{Y}=14.9 x \mathrm{e}^{-0.39 x}+4.6$ & 2 & 129.4 & 0.0274 \\
manure & Error & 2 & 3.6 & \\
Canola on turkey & Model: $\mathrm{Y}=15.2\left(1-\mathrm{e}^{-(0.39 x+0.11)}\right)$ & 2 & 27.17 & 0.0030 \\
compost & Error & 2 & 0.08 & \\
Canola on turkey & Model: $\mathrm{Y}=26.2\left(1-\mathrm{e}^{-(0.30 x+0.05)}\right)$ & 2 & 230.7 & 0.0063 \\
litter & Error & 2 & 1.45 & \\
Canola on beef & Model: $\mathrm{Y}=5.97\left(1-\mathrm{e}^{-(0.39 x+0.27)}\right)$ & 2 & 9.4777 & 0.0011 \\
manure & Error & 2 & 0.0103 & \\
Wheat on turkey & Model: $\mathrm{Y}=10.8\left(1-\mathrm{e}^{-(0.42 x+0.24)}\right)$ & 2 & 35.3879 & 0.0011 \\
compost & Error & 2 & 0.0401 & \\
Wheat on turkey & Model: $\mathrm{Y}=13.7\left(1-\mathrm{e}^{-(0.98 x+0.16)}\right)$ & 2 & 93.2517 & 0.0016 \\
litter & Error & 2 & 0.1483 & \\
Wheat on beef & Model: $\mathrm{Y}=12.08\left(1-\mathrm{e}^{-(0.24 x+0.22)}\right)$ & 2 & & 0.0071 \\
manure & Error & 2 & & \\
\hline & & & &
\end{tabular}




\subsection{Superiority of Turkey Compost over Turkey Litter and Beef Manure With Respect to Soybean Grain Production}

The maximum yield of soybean plants was $30 \%$ and $52 \%$ greater when plants were grown on soil amended with turkey compost than when the soil was amended with turkey litter and beef manure, respectively. These results are corroborated by the higher elongation rates observed when soybean plants were grown on soil amended with turkey compost (Figure 1 soybean-abcd) Regardless of the rate tested, turkey compost outperformed turkey litter and beef manure, with respect to soybean grain production. These results can be explained by the synergic effect of the richer composition of turkey compost (Table 4) and the specific nutrient requirements of soybean. Except for nitrogen, turkey compost supplied a greater content in all major and minor elements. As a leguminous plant, soybean can symbiotically fix atmospheric $\mathrm{N}_{2}$ to meet all its nitrogen needs. Hence, soybean seldom responds to $\mathrm{N}$ fertilization. However, its requirements for P and K are relatively large (Scott \& Adrich, 1983). Critical concentrations of nutrients in crop tissues, defined here as the element concentration in the tissue of the plant that that results in the maximum yield, can provide key information about the relative requirements by a crop for major and minor elements. In Canadian ecosystems, the critical levels of nutrients in soybean plants are: $\mathrm{N}$ (4.0\%); P (0.35\%); K (1.2\%); Ca (-); Mg (0.10\%); B (20.0 mg/kg); Cu (4.0 mg/kg); Mn (14.0 mg/kg); Mo (0.5 $\mathrm{mg} / \mathrm{kg}$ ); Zn (12 mg/kg) (Ontario Ministry of Agriculture and Rural Affairs [OMAFRA], 2002). These critical concentrations are lower for wheat: N (2.0\%); P (0.1\%); K (1.0\%); Ca (-); Mg (0.15\%); B (3 mg/kg); Cu (3 $\mathrm{mg} / \mathrm{kg}) ; \mathrm{Mn}(15 \mathrm{mg} / \mathrm{kg}) ; \mathrm{Zn}(10 \mathrm{mg} / \mathrm{kg})$. The same concentrations are generally intermediate for canola: $\mathrm{N}$ (2.4\%); P (0.24\%); K (1.4\%); Ca (0.49); Mg (0.19\%); B (29 mg/kg); Cu (2.6 mg/kg); Mn (14 mg/kg); Mo (0.02 $\mathrm{mg} / \mathrm{kg}) ; \mathrm{Zn}(14 \mathrm{mg} / \mathrm{kg})$, (Canola Council of Canada, 2003). It appears that under our experimental conditions, the higher nutrients supply from turkey compost matched the higher specific nutrients requirement by soybean plants.

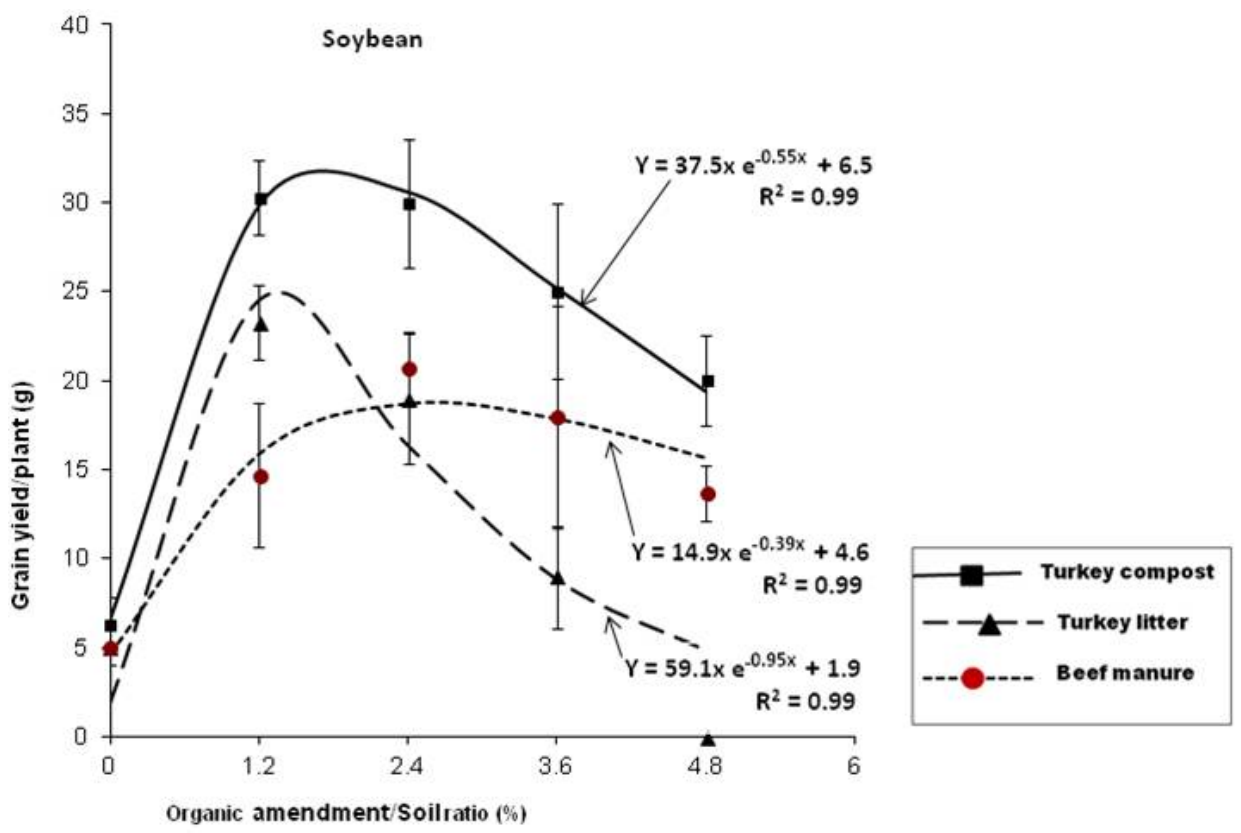

Figure 2. Transcendental concave grain yield response of soybean to increasing concentration of turkey compost, turkey litter, and beef manure in the soil (dry weight basis) 


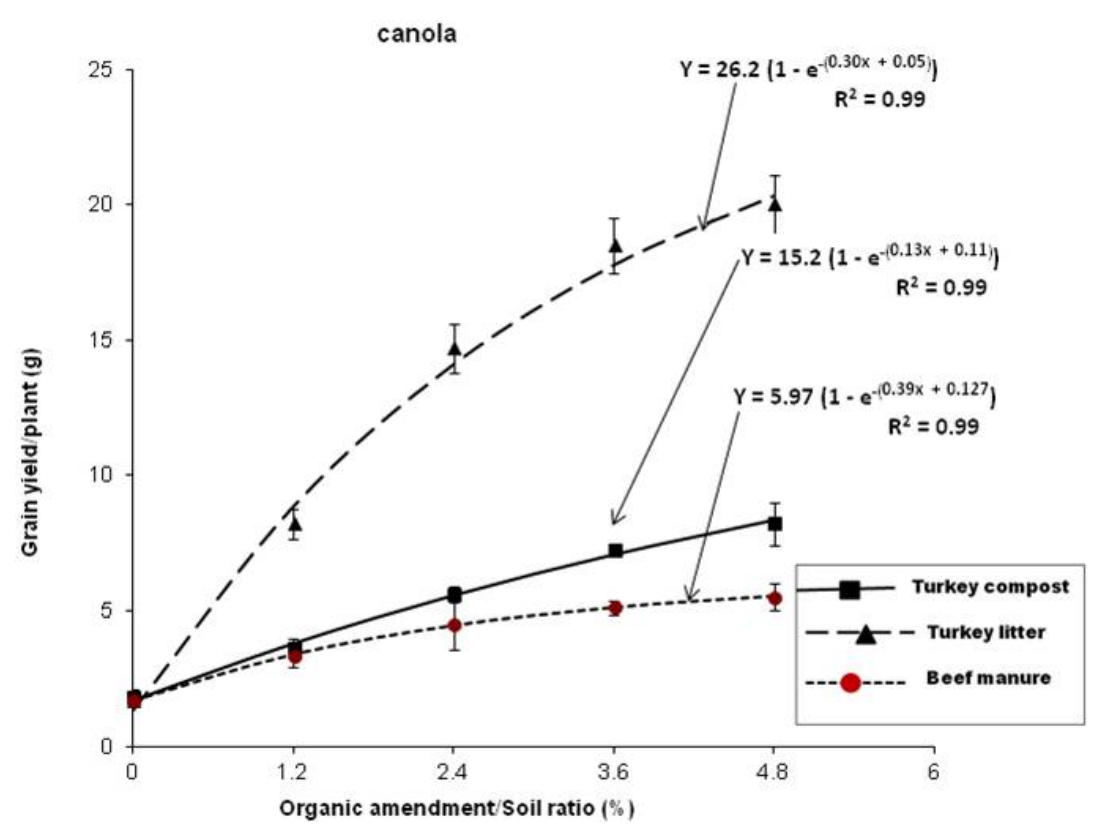

Figure 3. Negative exponential grain yield response of canola to increasing concentration of turkey compost, turkey litter, and beef manure in the soil (dry weight basis)

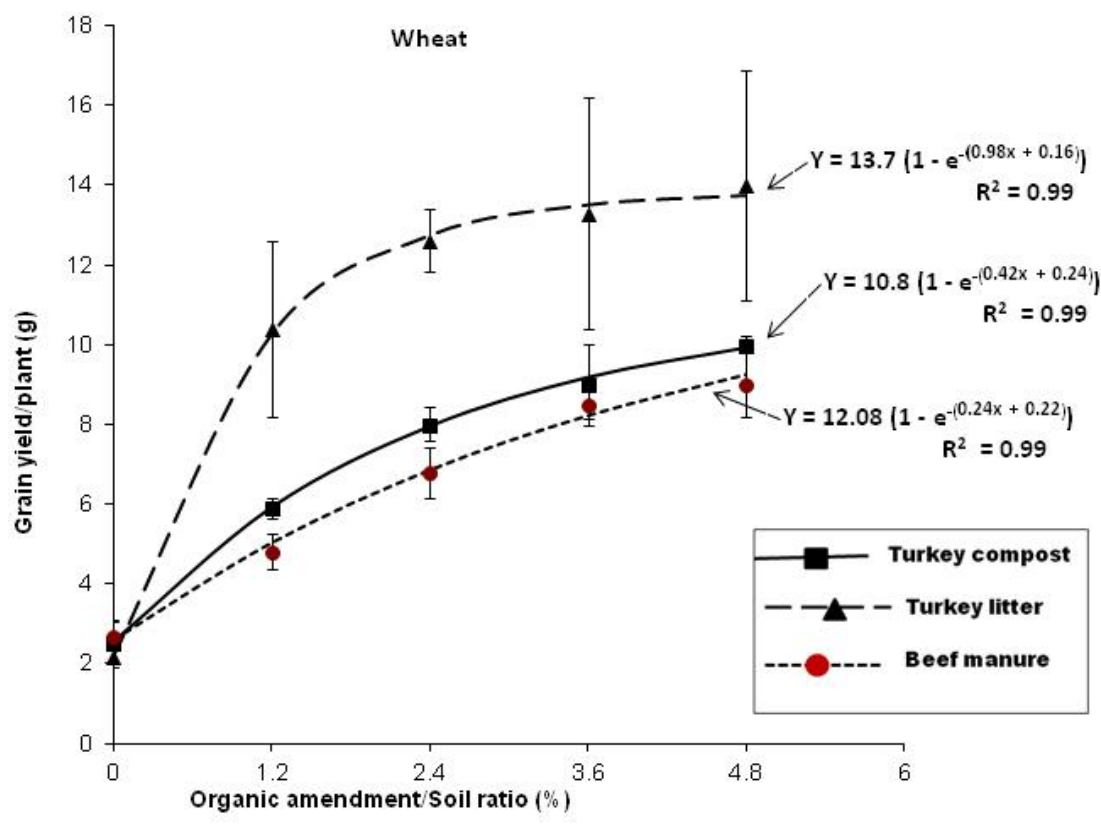

Figure 4. Negative exponential grain yield response of wheat to increasing concentration of turkey compost, turkey litter, and beef manure in the soil (dry weight basis)

\subsection{Soybean Phytotoxicity at High Rates of Turkey Compost, Turkey Litter and Beef Manure}

Unlike canola and wheat (non-leguminous), soybean (leguminous) grain yield responses displayed maximums and minimums as well as phytotoxicity effects, irrespective of the type of amendment used. Phytotoxicity is evidenced here by the dramatic reduction of growth rates of individual soybean plants when the rate of amendment is increased from $1.2 \%$ to $4.8 \%$ (38\% and $100 \%$ reduction with turkey compost and turkey litter, respectively) (Figure 1 soybean-abcd). In contrast, canola and wheat displayed a negative-exponential growth pattern regardless of the type of amendment they grew on. Despite a significant reduction in elongation rate, 42 days after seeding, observed when canola plants were grown on soil amended with turkey litter at $4.8 \%$ 
amendment rate (Figure 1 canola-d), this one ultimately provided the highest grain yield. This suggests that the type of crop response (concave or exponential) to increasing rates of organic amendment is dependent upon the crop's physiology, and perhaps upon the crop taxonomic group. The concave grain yield response of soybean and the negative exponential response of canola and wheat could be explained by their differing tolerance to soil salinity. Soybeans, like all grain legumes, are classified as species sensitive to soil salinity (Mass \& Hoffman, 1977; Katerji et al., 2000). Extensive field research has demonstrated the adverse impact of fresh and composted manure on soil salinity (Miller et al., 2005; Hao \& Chang, 2003) and crop growth and development (Chatrath et al., 2000). Studies on the effects of soil salinity on soybeans have shown that the greater the salinity, the lower the leaf-water potential, the stomatal conductance, the leaf surface, the number of pods/plant, the number of grains/pod, the yield, and the water-use-efficiency (Katerji et al., 2009; Van Hoorn et al., 2001). Thus, high levels of soil salinity would lead to water stress and reduced soybean growth and yield. In contrast, canola is moderately tolerant to salts and sodium. Canola plants survival is not significantly affected until salinity exceeds $0.56 \mathrm{~S} \mathrm{~m}^{-1}$ (Canola Council of Canada, 2003). Comparative evaluation of the effect of moderate root-zone salinity $\left(0.56 \mathrm{~S} \mathrm{~m}^{-1}\right)$ on the grain yields of canola, flax, Durum wheat, and field pea have shown that canola, flax and Durum wheat have similar soil salinity tolerance levels, whereas field pea's tolerance to soil salinity is 4 times lower than that of canola (Steppuhn, 2000). Interestingly, Durum wheat (Triticum durum) belongs to the same genus as wheat (Triticum aestivum) whereas field pea and soybean belong to the same Fabaceae family. Equally interesting, turkey compost and turkey litter had the highest electrical conductivity (EC) (0.58 and 0.54 $\mathrm{S} \mathrm{m}^{-1}$ respectively); and when increasing rates of these two organic amendments are mixed with a fixed volume of soil $(5 \mathrm{~kg})$, the EC of the amended soil is expected to increase. For turkey compost and turkey litter, rates beyond $1.2 \%$ (dry weight) resulted in a decreased growth and development expressed in terms of grain yield (Figure 2 soybean). Whereas beef manure had the lowest EC, and the grain yield of soybean was not negatively affected until the $3.6 \%$ rate was reached.

\subsection{Superiority of Turkey Litter Over Turkey Compost and Beef Manure With Respect to Canola and Wheat}

When compared to turkey compost composition, turkey litter supplied a lower amount of nutrients with the exception of ammonium (Table 4), yet it outperformed turkey compost when canola and wheat were the crops grown, irrespective of the rate used. The maximum yield of canola plants grown on soil amended with turkey litter was $144 \%$ and $264 \%$ greater than when plants were grown on soil amended with turkey compost and beef manure, respectively. These figures were respectively $40 \%$ and $56 \%$ for wheat. These results can be attributed to: i) a relatively higher $\mathrm{N}$ requirements by canola and wheat crops; ii) a greater tolerance to salinity by canola and wheat (see phytotoxicity section above). For illustration, under organic production conditions, canola $\left(2 \mathrm{t} \mathrm{ha}^{-1}\right)$, wheat $\left(2.7 \mathrm{tha}^{-1}\right)$, and corn $\left(6.3 \mathrm{tha}^{-1}\right)$ respectively require $62.5,35.2$, and $27.3 \mathrm{~kg} \mathrm{~N}^{-1}$ to produce one tonne of grain (Wallace, 2001). The high $\mathrm{NH}_{4}^{+}$content of turkey litter $\left(13,000 \mathrm{mg} \mathrm{kg}^{-1}\right)$ ensured the overall supply of nitrogen to canola throughout the growing season. High $\mathrm{N}$ requirements and tolerance to moderate salinity $(0.4$ to $0.8 \mathrm{~S} \mathrm{~m}^{-1}$ ) can explain the type and magnitude of responses observed on canola and wheat crops to increasing amount of turkey compost, turkey litter and beef manure.

Table 4. Amount of nutrients supplied per pot by turkey compost, turkey litter, and beef manure at $1.2 \%$ organic amendment/soil ratio. Values between parentheses $\left(\mathrm{mg} \mathrm{kg}^{-1}\right)$ represent total amended soil element concentrations. Nutrient values for $2.4,3.6$, and 4.8 amendment/soil ratios are obtained by multiplying corresponding " $1.2 \%$ values" by 2,3 , and 4 , respectively

\begin{tabular}{llll}
\hline & Turkey compost & Turkey litter & Beef manure \\
\hline Amendment/soil (\%) & $1.20 \%$ & $1.20 \%$ & $1.20 \%$ \\
Ammonium-N (mg) & $180(36)$ & $785(157)$ & $81(16)$ \\
Phosphorus (mg) & $762(152)$ & $534(107)$ & $73(14.6)$ \\
Calcium (mg) & $1842(392)$ & $726(169)$ & $360(96)$ \\
Potassium (mg) & $726(146)$ & $630(127)$ & $336(68)$ \\
Magnesium (mg) & $366(78)$ & $216(48)$ & $120(68)$ \\
Zinc (mg) & $21(4)$ & $20(4)$ & $1.3(0.3)$ \\
Manganese (mg) & $25(5)$ & $18(3.6)$ & $1.3(0.3)$ \\
Copper (mg) & $6(1)$ & $3(0.5)$ & $0.3(0.06)$ \\
Iron (mg) & $114(23)$ & $23(4.6)$ & $37(7.4)$ \\
Boron(mg) & $1.3(0.3)$ & $0.5(0.1)$ & $0.4(0.09)$ \\
\hline
\end{tabular}




\section{Conclusions}

To conclude, we have shown that under greenhouse conditions, the responses of soybean, canola, and wheat to increasing amounts of turkey compost, turkey litter, and beef manure vary in nature and magnitude depending upon the type of organic amendment used. Soybean is more sensitive to both rate and type of organic amendment than canola and wheat. The type of organic amendment applied to the soil affects the internode elongation rate and the grain yield of soybean plants, whereas canola elongation rate, unlike grain yield, is hardly affected by the type of organic amendment. Soybean, a leguminous crop, had its highest grain yield when it was grown on a soil amended with turkey compost; whereas canola and wheat produced greater yields when grown on soils amended with turkey litter. These findings suggest that grain yield in particular, and growth and development of plant species in general, can be optimized under greenhouse and perhaps field conditions through matching the most suitable type of organic amendment to the specific requirements of plant species. Further research is needed under field conditions as nutrient dynamics may differ significantly in the field. For example, nitrogen losses through runoff, leaching, volatilization and denitrification processes may be more pronounced under field conditions. In the case of ammonia for instance, major determinants for its volatilization and therefore its loss to the atmosphere are its concentration in the organic amendment, the $\mathrm{pH}$, and environmental factors such as solar radiation, temperature, and air velocity (Nkoa, 2014). These environmental factors are controlled under greenhouse settings. In the field, turkey litter would likely lose more ammonia through volatilization than turkey compost and beef manure due to its higher concentration in ammonia. This could change the magnitude of the observed responses.

\section{Conflict of Interest}

The authors declare no conflict of interest.

\section{Acknowledgements}

We are grateful to Cold Spring Farm Limited which provided the organic amendments; we thank organic farmers Francis Hartman and Wayne Weber who allowed us to collect organic topsoil from their farms.

\section{References}

Berger, J. D., Robertson, L. D., \& Cocks, P. S. (2002). Genotype x environment interaction for yield and other plant attributes among undomesticated Mediterranean Vicia species. Euphytica, 126, 421-435. http://dx.doi.org/10.1023/A:1019938300971

Beyene, Y., Mugo, S., \& Muntinda, C. (2011). Genotype by environment interactions and yield stability of stem borer resistant maize hybrids in Kenya. African Journal of Biotechnology, 10, 4752-4758.

Canola Council of Canada. (2003). Acidity, salinity, solonetzic. In: Canola Growers Manual, (pp. 603-604). Winnipeg, Manitoba: Canola Council of Canada.

Chatrath, A., Mandal, P. K., \& Anuradha, M. (2000). Effect of secondary salinization on photosynthesis in fodder oat (Avena sativa L.) genotypes. Journal of Agronomy and Crop Science, 184, 13-16. http://dx.doi.org/10.1046/j.1439-037x.2000.00333.x

Cohen, J. E. (2003). The human population: next half century. Science, 320, 1172-1175. http://dx.doi.org/10.1126/science.1159146

Gonzalez, R. F., \& Cooperband, L. R. (2002). Compost effect on soil physical properties and field nursery $\begin{array}{lllll}\text { production. Compost } & \text { Science and }\end{array}$ http://dx.doi.org/10.1080/1065657X.2002.10702084

Hao, X., \& Chang, C. (2003). Does long-term heavy cattle manure application increase salinity of a clay loam soil in semi-arid southern Alberta? Agriculture, Ecosystem and Environment, 94, 89-103. http://dx.doi.org/10.1016/S0167-8809(02)00008-7

Hati, K. M., Mandal, K. G., Misra, A. K., Gosh, P. K., \& BandyoPadhyay, K. K. (2006). Effect of inorganic fertilizer and farmyard manure on soil physical properties, root distribution and water-use efficiency of soybean in Vertisol of central India. Bioresource Technology, 97, 2182-2188. http://dx.doi.org/10.1016/j.biortech.2005.09.033

Katerji, N., Mastrorilli, M., Lahmer, F., \& Hamdy, A. (2009). Effect of soil texture and soil salinity on the plant water relationship, growth, yield and water use efficiency of the soybean crop. In S. Davies, G. Evans, (Eds.) Soybean and wheat crops: growth, fertilization, and yield (pp. 23-37). New York: Nova Science Publishers.

Katerji, N., Van Horn, J. W., \& Hamdy, A. (2000). Salt tolerance classification of crops according to soil salinity 
and to water stress day index. Agricultural Water Management, 43, 99-109. http://dx.doi.org/10.1016/S0378-3774(99)00048-7

Lafleur, B., Thiffault, E., Pare, D., Camire, C., Bernier-Cardou, M. ... Masse. (2012). Effects of hog manure application on the nutrition and growth of hybrid poplar (Populus spp.) and on soil solution chemistry in short-rotation woody crops. Agriculture, Ecosystem and Environment, 155, 95-104. http://dx.doi.org/10.1016/j.agee.2012.04.002

Lal, R. (2009). Soils and sustainable agriculture. In: E. Lichtfouse, M. Navarete, P. Debaeke, S. Veronique, C. Alberola (Eds.), Sustainable agriculture (pp. 15-23.). Netherlands: Springer. http://dx.doi.org/10.1007/978-1-4020-9654-9_3

Larney, F. J., Janzen, H. H., Olson, B. M., \& Lindwall, C. W. (2000). Soil quality and productivity responses to simulated erosion and restorative amendments. Canadian Journal of Soil Science, 80, 515-522. http://dx.doi.org/10.4141/S99-100

Lazcano, C., Revilla, P., Malvar, R. A, \& Dominguez, J. (2011). Yield and fruit quality of four sweet corn hybrids (Zea mays) under conventional and integrated fertilization with vermicompost. Journal of the Science of Food and Agriculture, 91, 1244-1253. http://dx.doi.org/10.1002/jsfa.4306

Maas, E. V., \& Hoffman, G. J. (1977). Crop salt tolerance, current assessment. Journal of Irrigation and Drainage Engineering, 103, 115-134.

Marschner, P. (2012). Mineral nutrition of higher plants. (3rd ed.), San Diego, USA: Academic Press. http://dx.doi.org/10.1016/B978-0-12-384905-2.00022-4

Maynard, A. A. (1998). Using MSW (municipal solid waste) compost in nursery stock production. Biocycle, 39, 63-65.

Melnitchouck, A., \& Hodson, M. (2004). Genotype x environment interaction in the uptake of Cs and Sr from soils by plants. Journal of Plant Nutrition and Soil Science, 167, 72-78. http://dx.doi.org/10.1002/jpln.200321273

Miller, J. J., Beasley, B. W., Larney, F. J., \& Olson, B. M. (2005). Soil salinity and sodicity after application of fresh and compostable manure wit straw or wood-chips. Canadian Journal of Soil Science, 85, 427-438. http://dx.doi.org/10.4141/S04-066

Mooleki, S. P., Schoenau, J. J., Charles, J., \& Wen, G. (2004). Effect of rate, frequency and incorporation of feedlot cattle manure on soil nitrogen availability, crop performance and nitrogen use efficiency in east-central Saskatchewan. Canadian Journal of Soil Science, 84, 199-210. http://dx.doi.org/10.4141/S02-045

Nizam, I., Cubuk, M. G., \& Moralar, E. (2011). Genotype x environment interaction and stability analysis of some Hungarian vetch (Vicia pannonica Crantz.) genotypes. African Journal of Agricultural Research, 6, 6119-6125. http://dx.doi.org/10.5897/AJAR11.1228

Nkoa, R. (2014). Agricultural benefits and environmental risks of soil fertilization with anaerobic digestates: a review. Agronomy for Sustainable Development, 34, 473-492. http://dx.doi.org/10.1007/s13593-013-0196-z

Nkoa, R., Desjardins Y., Tremblay, N. (2003). A mathematical model for nitrogen demand quantification and a link to broccoli glutamine synthetase activity. Plant Science, 165, 483-496. http://dx.doi.org/10.1016/S0168-9452(03)00167-5

OMAFRA. (2002). Guide Agronomique des Grandes Cultures. Toronto, Canad: Ontario Ministry of Agriculture, Food, and Rural Affairs.

Quian, P., Schoenau, J. J., Wu, T., \& Mooleki, S. P. (2003). Copper and zinc amounts and distribution in soil as influenced by application of animal manure in east-central Saskatchewan. Canadian Journal of Soil Science, 83, 197-202. http://dx.doi.org/10.4141/S02-063

Raviv, M. (2005). Production of high-quality composts for horticultural purposes: a mini-review. Horttechnology, $15,52-57$.

Rotz, C. A., Kleinman, P. J. A., Dell, C. J., Veith, T. L., \& Beegle, D. B. (2011). Environmental and economic comparisons of manure application methods. Journal of Environmental Quality, 40, 438-448. http://dx.doi.org/10.2134/jeq2010.0063

SAS/STAT Institute Inc. (1996). SAS/STAT user's guide, Release 6.12 Edition. Cary, NC: SAS Institute Inc. 
Saviozzi, A., Biasci, A., Riffaldi, R., \& Levi-Minzi, R. (1999). Long-term effects of farmyard manure and sewage sludge on some soil biochemical characteristics. Biology and Fertility of Soils, 30, 100-106. http://dx.doi.org/10.1007/s003740050594

Schoenau, J. J., \&. Davis, J. G. (2006). Optimizing soil and plant responses to land-applied manure nutrients in the Great Plains of North America. Canadian Journal of Soil Science, 86, 587-595. http://dx.doi.org/10.4141/S05-115

Scott, W. O., \& Aldrich, S. R. (1983). Modern soybean production. Champaign, Illinois, USA: S \& A Publications, Inc. http://dx.doi.org/10.1080/00207548308942340

Sommer, S. G., \& Hutchings, N. J. (2001). Ammonia emission from applied manure and its reduction -Invited paper. European Journal of Agronomy, 15, 1-15. http://dx.doi.org/10.1016/S1161-0301(01)00112-5

Steppuhn, H. (2000). Salinity delays and restricts the emergence of alternative crops. Research Newsletter No. 6 March 31 2000, Swift Current, SK: Semiarid Prairie Agricultural Research Centre.

Thanki, H. P., Sawargaonkar, S. L., \& Hudge, B. V. (2010). Genotype x environment interaction for biometrical traits in pigeonpea (Cajunus cajan L. Millsp.) under varying spacings. Electronic Journal of Plant Breeding, $1,925-928$.

Van Hoorn, J. W., Katerji, N., Hamdy, A., \& Mastrorilli, V. (2001). Effect of salinity on yield and nitrogen uptake of four grain legumes and on biological nitrogen contribution from the soil. Agricultural Water Management, 51, 87-98. http://dx.doi.org/10.1016/S0378-3774(01)00114-7

Wallace, J. (2001). Guide to organic production of field crops (French) (2nd ed). Ottawa, Ontario: Canadian Organic Growers Inc.

Wong, J. W. C., Ma, K. K., Fang, K. M., \& Cheung, C. (1999). Utilization of a manure compost for organic farming in Hong Kong. Bioresource Technology, 67, 43-46. http://dx.doi.org/10.1016/S0960-8524(99)00066-8

Zaller, J. G., \& Köpke, U. (2004). Effect of traditional and biodynamic farmyard manure amendment on yields, soil chemical, biochemical and biological properties in a long-term field experiment. Biology and Fertility of Soils, 40, 222-229. http://dx.doi.org/10.1007/s00374-004-0772-0

\section{Copyrights}

Copyright for this article is retained by the author(s), with first publication rights granted to the journal.

This is an open-access article distributed under the terms and conditions of the Creative Commons Attribution license (http://creativecommons.org/licenses/by/3.0/). 